\title{
PRUNING TYPE AFFECTS DECAY AND STRUCTURE OF CRAPEMYRTLE
}

\author{
By Edward F. Gilman' ${ }^{1}$ and Gary W. Knox ${ }^{2}$
}

\begin{abstract}
Lagerstroemia $\times$ 'Natchez' trees were topped, pollarded, or not pruned for 4 consecutive years. The first time trees were pruned in 1998, pollarding required more time than topping. However, the time required to top trees increased in each subsequent year; pollarding time remained the same for each year. Longitudinal sections through stems showed that barrier zones and decay extended farther behind heading cuts on topped trees 5 years after the initial pruning than with the cuts on pollarded trees. Trees in the topping treatment formed a visible, dark-colored barrier zone along the cambium present at the time of wounding, averaging $74 \mathrm{~cm}$ ( $2.5 \mathrm{ft})$ in length, originating from the heading cuts made through 4- to 5-year-old wood. Barrier zone length on pollarded trees was only $1.8 \mathrm{~cm}$ ( $0.7 \mathrm{in})$ behind the original heading cuts through 2-to 3 -year-old wood. Topping trees resulted in a sixfold increase in the volume of wood contained in dead stubs in the canopy compared to pollarding trees. Topping increased the need for cleaning the canopy of dead branches. A collar formed at the base of sprouts that were less than 0.64 the diameter of the largest sprout 5 years after the original heading cuts on trees in the topped treatment.
\end{abstract}

Key Words. Pollarding; topping; barrier zone; decay; restoration pruning; canopy cleaning.

Several techniques are used to reduce or maintain the size of a tree canopy. Topping uses heading cuts through wood more than several years old to shorten all stems and branches. Tipping is similar to topping except heading cuts are made through smaller-diameter branches toward the outer edge of the canopy. Some arborists refer to this as rounding over. Crown reduction makes the canopy smaller by shortening stems and branches with reduction cuts back to live lateral branches (Gilman and Lilly 2002). Pollarding makes heading cuts through branches up to about 3 years old and annually removes all or most sprouts back to the original heading cuts (Harris et al. 2004). Pollarding was used extensively in Europe to maintain trees at a small size (Raimbault 1996). Pollarded trees can live longer than nonpollarded trees (Lonsdale 1999). Topiary shears new growth in a hedgelike manner to maintain size.

Topping can cause massive decay in certain trees that compartmentalize decay poorly, or it can cause little decay in good compartmentalizers (Boddy and Rayner 1983; Shigo 1989; Schmidt and Liese 1993). Topped trees have been reported to be structurally weak compared to trees that have not been topped (ANSI 2001). A barrier zone forms at the current location of the cambium in wood behind a topping or flush cut. The barrier zone is chemically and anatomically different from wood formed prior to and subsequent to injury and often appears darker than nearby wood (Tippett and Shigo 1980). It is often visible to the naked eye in cross section and longitudinal section.

Suberin is a common component of barrier zones in species considered good compartmentalizers of decay (Pearce and Rutherford 1981). Suberin may be absent from trees that compartmentalize decay poorly. Suberin increases effectiveness of the barrier zone against wood decay fungi, probably by repelling water and fungi (Pearce 1990).

Cutting back or heading all crapemyrtle stems in the nursery to encourage sprouting is common practice in production horticulture (Arnold 2003). Rounding over the canopy of crapemyrtle in landscapes using heading cuts through 1- to 3-year-old wood is common in the southern United States. Topping the canopy with heading cuts through older wood is also common. These landscape practices apparently are based on tradition because there is no research supporting or refuting them as good horticulture.

The purpose of this research was to determine how crapemyrtle reacts to topping and pollarding compared to trees not pruned.

\section{MATERIALS AND METHODS}

Lagerstroemia $\times$ 'Natchez' crapemyrtle were planted 6 m (20 $\mathrm{ft}$ ) apart into Leefield fine sandy soil in USDA hardiness zone 8 b near Tallahassee, Florida, U.S., February 24, 1994, from \#5 containers. Trees averaged $4 \mathrm{~m}(13.2 \mathrm{ft})$ tall and 3.4 m (11.3 ft) wide at the end of 1997. In March 1998, all trees were pruned to remove dead branches, rubbing trunks, and crossing stems. The same month, trees received one of three treatments: not pruned, topped, or headed to initiate pollarding. Ten trees received each of the three treatments arranged in a randomized complete block design for a total of 30 trees. One tree for each treatment was placed in each block. Trees were irrigated and fertilized regularly.

The first pruning in March 1998 made heading cuts through 2- to 3-year-old wood (18 $\mathrm{mm}$ [0.7 in.] diameter) 1.8 to $2.4 \mathrm{~m}$ ( 6 to $8 \mathrm{ft}$ ) from the ground on the pollarding treatment, and through 4- to 5-year-old wood $(27 \mathrm{~mm}$ [1.1 in.] diameter) 1.2 to $1.5 \mathrm{~m}$ ( 4 to $5 \mathrm{ft}$ ) from the ground on the 
topping treatment. The number of visible growth increments determined age of the cut stems. The entire top portion of each of the 20 pruned trees was removed. Each tree was pruned once each year just prior to new growth in the spring (February, March, or April) for 4 years. Heading cuts on topped trees in the second, third, and fourth years were made through the 1-year-old sprouts that grew from the previous year's heading cuts. Topped trees were pruned 15 to $20 \mathrm{~cm}$ ( 6 to 8 in.) beyond the heading cuts made the previous year (Figure 1, upper left). The location of buds along the cut stems was not considered in choosing the position of the cut; the cuts were positioned to present a uniform canopy following pruning similar to what is commonly performed in southern U.S. landscapes (Figure 1, upper left). All sprouts on pollarded trees were removed each year back to the point of the original heading cut (Figure 1, lower left). Swollen tissue (referred to as a pollard head) developed at this point on all pollarded trees. Only small, low branches on trees in the not pruned treatment were removed to allow for clearance under the canopy.

Time required to pollard or top each tree was recorded every year through 2001. At the conclusion of the study, 4 years after the initial pruning, total volume, length, and number of dead stubs in the canopy on three topped trees and three pollarded trees were calculated by measuring the length and diameter of all dead stubs. Presence or absence of a collar on topped trees was visually evaluated at the end of the 4-year study at the base of sprouts that grew from the original heading cuts made the first year.

Three pollard heads on three randomly selected trees (nine pollard heads total) and three topping cuts on three topped trees (nine cuts total) and the associated stem below were split longitudinally through the pith in fall 2002. Decay and length of the barrier zone (Rier and Shigo 1972) were recorded from the pruning cut basipetal down the stem. Extent of the barrier zone was evaluated by presence of a dark line along the position of the cambium that was present at the time the original heading cut was made (1998). The length

of discolored wood or the decay column was measured on each longitudinal section Each of these 18 heading cuts was evaluated for completeness of woundwood closure. Three stems on three trees that were not pruned were also cut at $1.8 \mathrm{~m}$ (6 ft) from the ground and split longitudinally below the cut at the end of the 4-year study to determine presence of barrier zones and decay.

Barrier zone length, length of discolored or decayed wood, and number, length, and volume of dead stubs were analyzed with ANOVA. Means were compared with Duncan's multiple range test and were considered significantly different from each other at $P<0.01$. Slopes of the lines correlating pruning time with year were compared using a t-test.

\section{RESULTS AND DISCUSSION}

Pollarding trees required more time than topping the first time trees were pruning in 1998 (Figure 2). However, time required to top trees increased in each subsequent year $(P<0.01)$; pollarding time remained the same for each year. By 2001, trees in both treatments required the same amount of time to prune.

Four years after the first pruning cuts, woundwood grew completely over original heading cuts on all pollarded trees and on seven of nine cuts on topped trees. This was not surprising because the original heading cuts on pollarded trees were significantly smaller in diameter than on topped trees (Table 1). Barrier zones, discolored wood, and decay extended farther back behind heading cuts 4 years after pruning through 4- to 5-year-old wood in the topping treatment than cuts made through 2-to 3-year-old wood in the pollarded trees (Table 1). The barrier zone corresponded with the edge of the heading cuts viewed in longitudinal section (Figure 1, upper right). The larger-diameter heading cuts made in the topping treatment would not be recommended due to the potential for wood decay, disfunction, and cracks.

There were no discoloration or barrier zones in new wood produced on the portion of the tree left after the initial topping. This indicated that the heading cuts made through 1-year-old sprout wood each year following the original heading cuts did not result in barrier zones that extended into the original topped stem. A protection zone (Green et al. 1981) at the base of each sprout must have

\section{Table 1. Diameter of pruning cuts, length of barrier zone, and decay column length in longitudinal section behind heading cuts made through 2- to 3-year-old and 4- to 5-year- old wood 4 years after original heading cut. (Means are based on three stems on three trees in each treatment.)}

\begin{tabular}{|c|c|c|c|}
\hline Pruning treatment & $\begin{array}{l}\text { Mean diameter } \\
\text { of original } \\
\text { heading cut (mm) }\end{array}$ & $\begin{array}{l}\text { Mean length of } \\
\text { barrier zone (mm) }\end{array}$ & $\begin{array}{l}\text { Mean } \\
\text { decay/discoloration } \\
\text { column length }(\mathrm{mm})\end{array}$ \\
\hline Headed 2- to 3-year-old wood (pollard) & 18 (0.7 in.) $\mathrm{b}^{y}$ & 18 (0.7 in.) b & 8 (0.3 in.) b \\
\hline Headed 4- to 5-year-old wood (topped) & 27 (1.1 in.) c & 736 (29.0 in.) c & 58 (2.3 in.) c \\
\hline Not pruned & $0 \mathrm{a}$ & $0 \mathrm{a}$ & $0 \mathrm{a}$ \\
\hline
\end{tabular}

${ }^{2}$ Distance in longitudinal section from heading cut to end of decay or discoloration, whichever is longer.

${ }^{y}$ Means in a column are statistically different at $P<0.01$. 


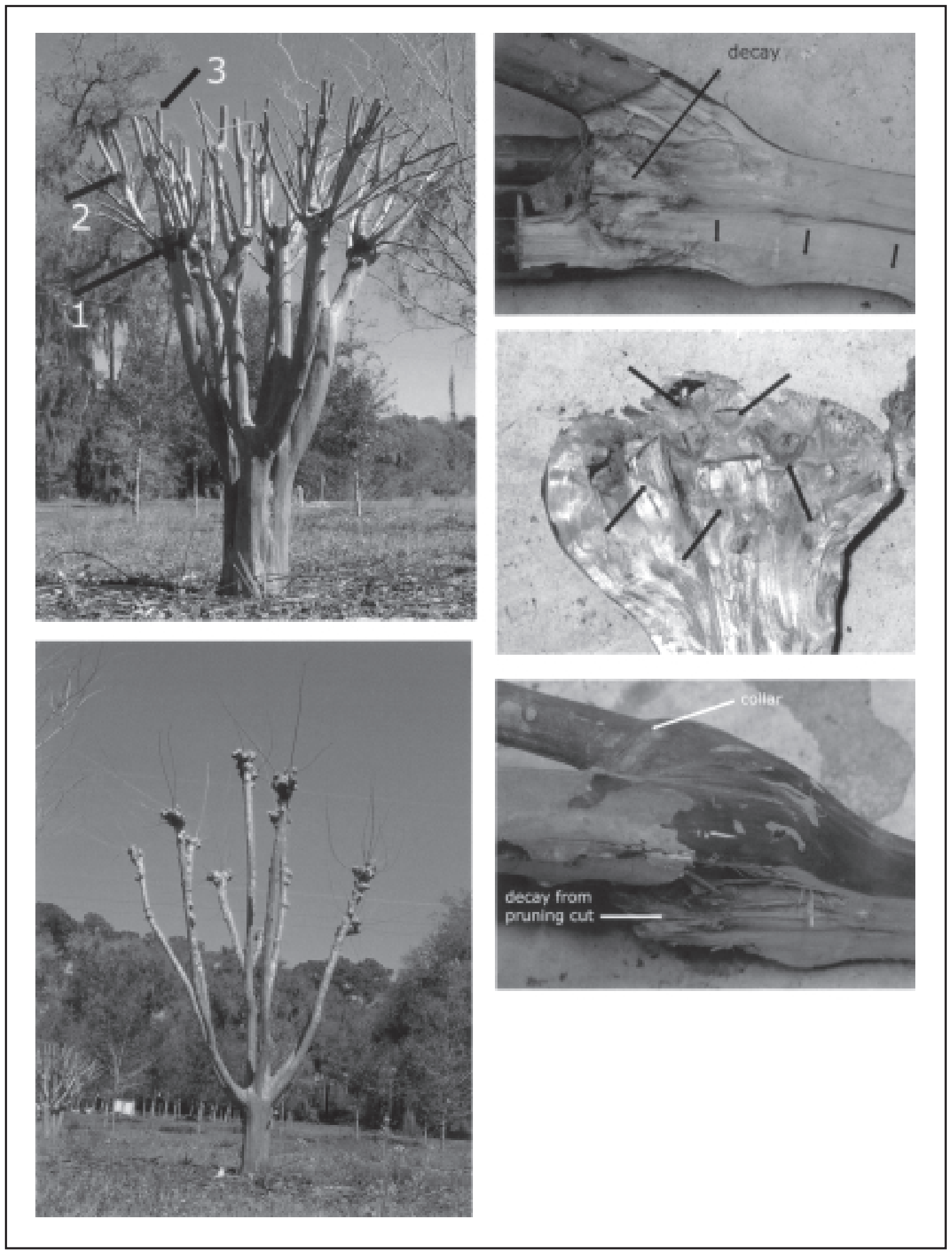

Figure 1. The first (1), second (2), and third year (3) pruning cuts are clearly visible on topped trees (upper left). Pollard heads were prominent after the fourth year of removing sprouts back to the same position (lower left). Decay is clearly visible on topped trees behind the original heading cut made in 1998 (upper right); the barrier zone can be seen streaking back behind the heading cut (three small arrows). Small pockets of decay were restricted to the base of all sprouts in the pollard heads (middle right); arrows indicate protection zones that retarded decay. Sprouts that remained small compared to the largest sprout formed a visible collar (lower right). 


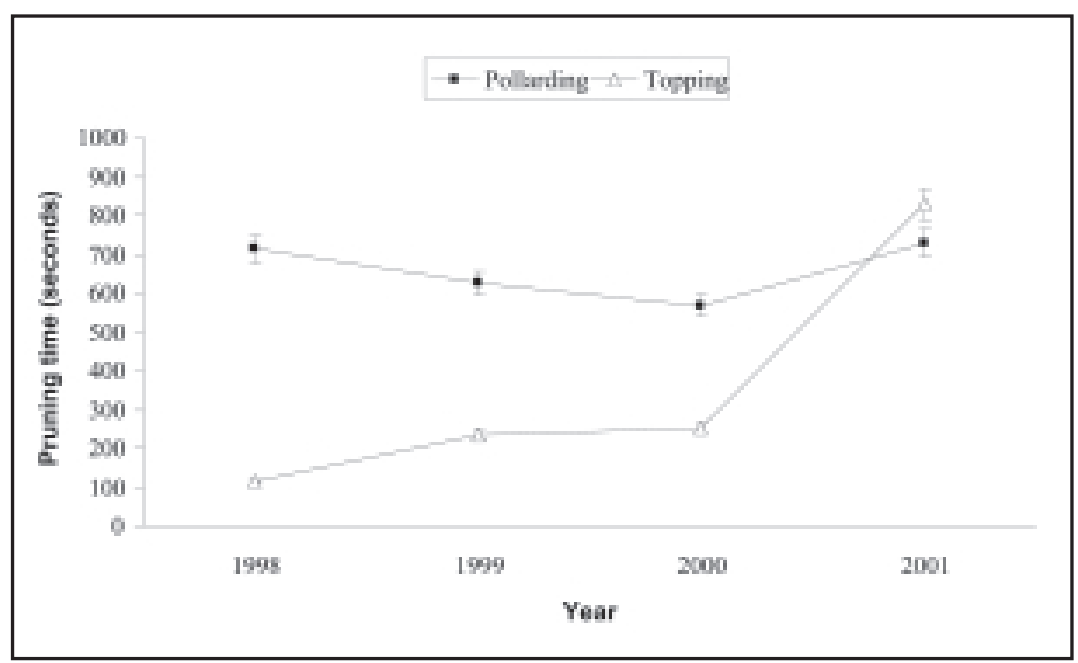

Figure 2. Time required to pollard or top crapemyrtle in four consecutive years. Standard error bar is shown around each mean. Each value is the mean of ten trees.

prevented formation of a barrier zone in new wood pro-

duced on the original cut stem.

The barrier zone formed along the cambium when trees were originally pruned limited the discoloration and decay to the diameter of the stems when trees were topped. Shigo (1989) and others have found similar results from years of research on many shade tree species. Discoloration and decay was typically triangular shaped in longitudinal section through the headed stems, suggesting a cone shape in three dimensions (Figure 1, upper right). 'Natchez' crapemyrtle appeared to be a good compartmentalizer, effectively retarding the longitudinal spread of decay indicated by the small area behind topping cuts (Table 1).

Pollard heads averaging $109 \mathrm{~mm}$ (4.3 in.) diameter developed in a more-or-less round fashion at the position of the original heading cut on all pollarded trees. Splitting the pollard heads in cross section and longitudinal section revealed a small zone of decayed wood at the position of each cut made each year (Figure 1, middle right). There were no instances of discoloration or decay streaking back into the pollard head. In other words, decay did not spread beyond the branch into the pollard head. Shigo and Marx (1977) reported good compartmentalization near pollard heads. This indicated the presence of a branch protection zone (Eisner et al. 2002) at the base of each sprout. This can be seen in Figure 1, middle right. Except for this small area of discolored and decayed tissue, the pollard heads contained only blond, unblemished wood.

Topping resulted in a sixfold increase in the volume of wood contained in dead stubs in the canopy, compared to pollarded trees (Table 2). Dead stubs on topped trees resulted from internodal heading cuts. The portion of the stem behind the cut and distal to the first live buds died because there was no living tissue to support it. This did not occur on pollarded trees because sprouts were cut back to their base on the pollard head each year. There was a collection of live buds at the base of crapemyrtle sprouts that gave rise to the next year's sprouts. Whereas pollarded trees presented a neat appearance with few visible dead stubs (mean length $3.5 \mathrm{~mm}$ [0.15 in.]), dead stubs in topped trees were clearly visible (mean length of 23 $\mathrm{mm}$ [0.9 in.]), presenting a sloppy appearance. Some stubs on topped trees were more than 80 $\mathrm{mm}$ (3 in.) long. Removing dead stubs and branches from the canopy is considered one of the major pruning types (referred to as cleaning) in the national pruning standard (ANSI 2001) and is practiced by many tree services. This study showed that pruning trees by topping increased the need for cleaning and makes a case against topping as a standard practice for maintaining crapemyrtle.

Five years after the original heading cuts on topped trees, some of the smaller sprouts formed collars near their base where they joined with the largest sprout (Figure 1, lower right). This point was at the position of the first heading cut made in 1998. The largest sprout growing from the topping cut never formed a branch collar. Sprouts with visible collars averaged 0.64 of the diameter of the largest sprout originating on the same stem. Sprouts without collars averaged 0.84 of the diameter of the largest sprout. Collars often form around branches that are small compared to the stem on which it grows (Gilman 2003), and branches with collars typically contain wood capable of forming a branch protection zone (Eisner et al. 2002). This helps retard the spread of decay following branch death or a pruning cut. Branches with collars are also better secured to the trunk than branches with bark inclusions (Smiley 2003) or branches that are large compared to the trunk (Gilman 2003). This suggests that structure on topped trees could be improved by allowing one sprout to grow larger in diameter than all others. Further study is needed to determine whether we can induce this to occur with pruning.

\section{CONCLUSION}

Pollarding appears to be a better method than topping for maintaining crapemyrtle at the same height for many years with only minimum structural defects inside the tree and a small amount of dead branch stubs in the canopy.

\section{LITERATURE CITED}

Arnold, M.A. 2003. Origin of multiple trunks affects crapemyrtle post-transplant establishment.

HortTechnology 13:120-127. 
Table 2. Number, length, and volume of dead stubs ${ }^{z}$ greater than $6 \mathrm{~mm}(0.25 \mathrm{in}$.) diameter in the canopy following 4 years of different pruning treatments on crapemyrtle. (Means are based on three stems on three trees in each treatment.)

\begin{tabular}{|c|c|c|c|}
\hline Pruning treatment & $\begin{array}{l}\text { Mean } \\
\text { number of } \\
\text { dead stubs/tree }\end{array}$ & $\begin{array}{l}\text { Mean } \\
\text { length of } \\
\text { of dead stubs (mm) }\end{array}$ & $\begin{array}{l}\text { Mean volume of } \\
\text { dead stubs/tree (mm) }\end{array}$ \\
\hline Headed 2- to 3-year-old wood (pollard) & $27.3 b^{y}$ & 3.5 (0.14 in.) b & $644 \mathrm{~b}$ \\
\hline Headed 4- to 5-year-old wood (topped) & $105.0 \mathrm{c}$ & 23.1 (0.91 in.) c & $3612 c$ \\
\hline Not pruned & $0 \mathrm{a}$ & $\mathrm{Oa}$ & $0 \mathrm{a}$ \\
\hline
\end{tabular}

American National Standards Institute (ANSI). 2001. American National Standard for Tree Care OperationsTree, Shrub, and Other Woody Plant MaintenanceStandard Practices (Pruning) (A300, Part 1). Tree Care Industry Association, Manchester, $\mathrm{NH}$.

Boddy, L., and A.D.M. Rayner. 1983. Origins of decay in living deciduous trees: The role of moisture content and the re-appraisal of the expanded concept of tree decay. New Phytol. 94:623-641.

Eisner, N., E.F. Gilman, J. Grabosky, and R.C. Beeson. 2002. Branch morphology impacts compartmentalization of pruning wounds. J. Arboric. 28:99-105.

Gilman, E.F. 2003. Branch-to-stem diameter ratio affects strength of attachment. J Arboric. 29:291-293.

Gilman, E.F., and S. Lilly. 2002. Best Management Practices: Tree Pruning. International Society of Arboriculture, Champaign, IL. 35 pp.

Green D.J., W.C. Shortle, and A.L. Shigo. 1981. Compartmentalization of discolored and decayed wood in red maple branch stubs. For. Sci. 27:519-522.

Harris, R., J. Clark, and N. Matheny 2004. Arboriculture: Integrated Management of Landscape Trees, Shrubs, and Vines (4th ed.). Prentice Hall, Upper Saddle River, NJ. 578 pp.

Lonsdale, D. 1999. Principles of Tree Hazard Assessment and Management. Stationary Office, Norwich, England. 388 pp.

Pearce, R.B. 1990. Occurrence of decay-associated xylem suberization in a range of woody species. Eur. J. For. Path. 20:275-289.

Pearce, R.B., and J. Rutherford. 1981. A wound-associated suberization barrier to the spread of decay in the sapwood of oak. (Quercus robur). Physiol. Plant Pathol. 19:359-369.

Raimbault, P. 1996. Unique Pruning Techniques Used in France. Abstract, ISA annual conference, Cleveland $\mathrm{OH}$.
Rier, J.P., and A.L. Shigo. 1972. Some changes in red maple, Acer rubrum, tissues within 34 days after wounding in July. Can. J. Bot. 50:1783-1784.

Schmidt, O., and W. Leise. 1993. Response of xylem parenchyma by suberization in some hardwoods after mechanical injury. Trees 8:23-30.

Shigo, A. 1989. Tree Pruning: A Worldwide Photo Guide. Shigo and Trees, Associates, Durham, NH. 186 pp.

Shigo, A., and H.G. Marx. 1977. Compartmentalization of Decay in Trees. USDA Forest Service, Agriculture Information Bulletin 405.73 pp.

Smiley. T. 2003. Does included bark reduce the strength of codominant stems? J. Arboric. 29:104-106.

Tippett, T.J., and A. Shigo. 1980. Barrier zone anatomy in red pine roots invaded by Heterobasibion annosum. Can. J. Bot. 30:224-232.

Acknowledgments. Florida Agriculture Experiment Station Journal Series No. R-10612.

${ }^{1 *}$ Professor

Environmental Horticulture Department

University of Florida

1545 Fifield Hall

P.O. Box 110670

Gainesville, FL 32611-0670, U.S.

${ }^{2}$ Professor

North Florida Research and Education Center

University of Florida

Gainesville, FL 3261-0670, U.S.

*Corresponding author. 
Résumé. Des Lagerstroemia $\times$ 'Natchez' ont été écimés, élaguées en «queues de lion » ou encore laissés tels quels durant quatre années consécutives. La première fois que les arbres ont été élagués en 1998, ceux taillés en « queues de lion » ont exigé plus de temps que ceux écimés. Cependant, le temps requis pour écimer les arbres s'est accrû dans chacune des années subséquentes alors que celui requis pour la taille en «queues de lion » est demeuré similaire. Cinq années après le premier élagage, les sections longitudinales des branches présentaient des zones de barrières et de carie qui s'étendaient bien au-delà des zones de coupe chez les arbres écimés, et ce par comparaison avec les coupes sur les arbres élagués en « queues de lion ». Les arbres écimés avaient formé une zone de barrière visible et avec une coloration très foncée le long du cambium au moment où la coupe a été faite, et ce avec une moyenne de $74 \mathrm{~cm}$ de longueur depuis la zone de la coupe dans le bois âgé de 4 à 5 ans. La longueur de la zone de barrière dans les arbres élagués « queues de lion » était de seulement 1,8 cm derrière la coupe originale dans le bois de 2 à 3 ans. Lécimage a résulté en un accroissement de six fois du volume de bois contenant des chicots morts dans la cime, et ce comparativement avec l'élagage en « queues de lion». Lécimage a accrû les besoins en nettoyage de la cime relativement à la présence de branches mortes. Un collet s'est formé à la base des rejets; ce collet faisait moins de $0,64^{e} \mathrm{du}$ diamètre du plus gros rejet, et ce cinq ans après les premières coupes faites sur les arbres écimés.

Zusammenfassung. Über vier aufeinander folgende Jahre wurden Lagerstroemia $\times$,Natchez' Bäume geköpft, zurückgeschnitten oder gar nicht geschnitten. Die Bäume wurden zum ersten Mal in 1998 geschnitten, rückgeschnittene Bäume erforderten mehr Zeitaufwand als geköpfte. Dennoch erforderte das Köpfen der Bäume in den nachfolgenden Jahren immer mehr Zeit, während der Rückschnitt zeitlich gleich blieb. Längsschnitte durch die Stämme zeigten, dass die Barrierezonen und die Fäule fünf Jahre nach dem Köpfen weit hinter den Schnitt zurückführen, mehr als bei den zurückgeschnittenen Bäumen. Die Bäume, die geköpft wurden, bildeten eine dunkel gefärbte Barrierezone entlang des Kambiums zur Zeit der Wundentstehung mit durchschnittlich 74 cm in der Länge, die aus Kopfschnitten durch 4-5-Jahre altes Holz gemacht wurden. Die Barrierezonen von zurückgeschnittenen Bäumen waren nur 1,8 cm hinter den Originalschnitten in 23jährigem Holz. Das Köpfen führte zu sechsfacher Steigerung von Totholz in den Kronen gegenüber zurückgeschnittenen Bäumen. Das Köpfen steigerte die Totholzbildung und den erforderlichen Pflegeaufwand. Um die Ansätze der Jungtriebe formten sich Wülste, die 0,64 des Durchmessers der größten Triebe fünf Jahre nach dem ersten Schnitt der Bäume in der Kopfschnittbehandlung hatten.

Resumen. Árboles de Lagerstroemia × 'Natchez' fueron sometidos al desmoche, al "pollarding" o no fueron podados, por cuatro años consecutivos. La primera vez que los árboles fueron cortados en 1998, los de pollarding requirieron más tiempo que los de desmoche. Sin embargo, el tiempo requerido para desmochar los árboles aumentó en los años subsiguientes, mientras el del pollarding permaneció igual cada año. Las secciones longitudinales de los tallos mostraron que las zonas de barrera y decaimiento se extendieron atrás de las heridas de las cortas en los árboles desmochados, cinco años después de la poda inicial que cortó los árboles de pollarding. Los árboles en los tratamientos de desmoche formaron una zona visible de barrera de color oscuro a lo largo del cambium presente en el momento de la herida, promediando 74 $\mathrm{cm}$. en longitud, originado de las heridas de las cortas hechas a través de 5 años. La longitud de la zona de barrera en árboles de pollarding fue solamente $1.8 \mathrm{~cm}$. atrás de las heridas originales en dos años. El desmoche resultó en un incremento en el volumen de madera contenida en los muñones muertos en la copa comparados con los árboles de pollarding. El desmoche incrementó la necesidad de limpieza de ramas secas de la copa. En los árboles desmochados se formó un collar en la base de los rebrotes que fue menor a 0.64 el diámetro del rebrote más largo, cinco años después de las heridas originales. 